\title{
LIFE CYCLE ASSESSMENT FOR OIL PALM BASED PLYWOOD: A GATE-TO-GATE CASE STUDY
}

\author{
${ }^{1}$ Shamim Ahmad, M., ${ }^{2}$ Vijaya Subramaniam, \\ ${ }^{2}$ Halimah Mohammad, ${ }^{2}$ Anis Mokhtar and ${ }^{1}$ B.S. Ismail \\ ${ }^{1}$ School of Environmental and Natural Resource Sciences, \\ Faculty of Science and Technology, Universiti Kebangsaan Malaysia, Bangi, Malaysia \\ ${ }^{2}$ Engineering and Processing Division, Malaysian Palm Oil Board, 43000 Kajang, Selangor, Malaysia
}

Received 2013-12-05; Revised 2014-02-25; Accepted 2014-03-15

\begin{abstract}
Life Cycle Assessment (LCA) is an important tool for identifying potential environmental impacts associated with the production of palm based plywood. This study is to make available the life cycle inventory for gateto-gate data so that the environmental impact posed by oil palm based plywood production can be assessed. Conducting an LCA on the palm based plywood that are derived from the wastes of the oil palm industry is a first step towards performing green environmental product. Therefore.establishing baseline information for the complete environmental profile of the palm oil plywood is essential. Data from this study on the environmental impact for the production of palm plywood would help to develop sustainable palm plywood product. The results will provide information to identify ways and measures to reduce the environmental impacts. Most foreground data were collected directly from numbers oil palm plywood factories which represent $40 \%$ of the palm plywood industry in Peninsular Malaysia. Data gaps were filled by information obtained through questionnaires which were developed specifically for data collection, literature, public database or further calculated from obtained data. The outputs and inputs from production activities were quantified on the basis of functional unit of production of $1 \mathrm{~m}^{3}$ from different types of oil palm based plywood i.e., Moisture Resistant (MR), Weather Boiling Proof (WBP) Grade 1 and Weather Boiling Proof (WBP) Grade 2. The life cycle impact assessment was carried out using SimaPro 7.1 software and the eco-indicator 99 methodology. The weighting results of LCA for the production of 1 cubic meter of oil palm based plywood showed significant impact in descending order i.e., fossil fuel, respiratory inorganic and climate change. The most significant process contributing to these environmental impacts came from the production and usage of adhesives, transportation of oil palm trunks from plantation to factory and generation and usage of electricity from the grid. The ways to mitigate the environmental impacts are by using substitutes for inorganic chemical adhesives such as groundnut shell lignin adhesive, modified phenol formaldehyde adhesive and developing wood adhesive made from pyrolisis oil of oil palm biomass, establishing a collecting centre for oil palm trunk transportation and efficient use of oil palm biomass as an energy source. The study helped establishing baseline information for the complete environmental profile of the palm oil industry from cradle to grave which starts at the oil palm germinated seeds to the production of palm plywood.
\end{abstract}

Keywords: Oil Palm, Plywood, Environment, Life Cycle Impact Assessment

\section{INTRODUCTION}

Life Cycle Assessment (LCA) is a process tool to evaluate the environmental impact associated with a product, process or activity by identifying and Corresponding Author: Shamim Ahmad, M. School of Environmental and Universiti Kebangsaan Malaysia, Bangi, Malaysia quantifying energy and materials used as well as waste released into the environment. LCA subsequently evaluates opportunities to effect environmental improvement. Nowadays, LCA has become a holistic environmental management tool. 
The oil palm industry is very important to the Malaysian economy. The export earnings from the export of palm products contributed about 5.9\% of Malaysia's Gross Domestic Product (BNM, 2011). As the world is demanding for economic growth which comes parallel with sustainability and quality of human life, LCA is a reliable and most advance tool in assessing the oil palm industry's environmental performance. LCA has been used to assess the production of oil palm seedling, oil palm fresh fruit bunch and crude palm oil (Halimah et al., 2010; Puah et al., 2010; Tan et al., 2010; Vijaya et al., 2010a; 2010b; Zulkifli et al., 2010; Choo et al., 2011; Halimah et al., 2012; Puah et al., 2013). In this study, LCA has been applied on the production of oil palm plywood, a downstream activity of the oil palm industry. The findings of these papers are very useful in improving the oil palm industry in Malaysia.

Currently, the annual availability of Oil Palm Trunks (OPT) is estimated at around 13.6 million logs based on 100,000 ha of replanting per year (UMP, 2002). Under specific controlled processing conditions to manufacture oil palm plywood, the total logs available can be converted into 4.5 million cubic meters of plywood. Plywood, a versatile wood paneling product, is in great demand by building contractors and furniture makers. Hardwood plywood may be pressed into panels or plywood components (e.g., curved hardwood plywood, seat backs, chair arms). Generally, hardwood plywood is used for interior applications such as furniture, cabinets, architectural millwork, paneling, flooring and doors. To date, palm plywood has been successfully manufactured and commercialized with the technical and collaborative support from the Malaysian government which has facilitated the production and commercialization of the product. The use of oil palm plywood currently is for non-structural materials used for such products as formworks, cabinets and packaging materials. Realizing the potential of oil palm plywood and the importance of environmental performance, LCA has been carried out on the production of oil palm plywood.

\section{MATERIALS AND METHODS}

The gate-to-gate LCA study was conducted according to the ISO standard (ISO, 2006). Life Cycle Impact Assessment (LCIA) and LCA were performed using SimaPro 7.1 (Netherlands). This software contains US and European databases on a wide variety of materials. The methodology selected to conduct LCIA was ecoindicator 99 (Goedkoop and Spriensma, 1999).

\subsection{Functional Unit}

The relevant functional unit of the system was used to provide the plywood with links to upstream plantation, midstream and downstream usage in construction. Therefore, the appropriate functional unit for this LCA study was $1 \mathrm{~m}^{3}$ of oil palm plywood.

\subsection{System Boundary}

In this study, the gate-to-gate system boundary was set to only include the production process of oil palm based plywood. The starting point would be at the plywood factory where the felled palm trunks were received up till the packaging of the oil palm based plywood. There are three types of oil palm plywood produced by two out of three factories located in Peninsular Malaysia i.e., Moisture Resistance palm plywood (MR), Weather Boiling Proof palm plywood (WBP) Grade 1 and Weather Boiling Proof palm plywood (WBP) Grade 2. This boundary was set to enable environmental assessment to be carried out only at the manufacturing phase as shown in Fig. 1.

\subsection{Allocation}

The two factories involved in this study produced different types of oil palm plywood. The first factory produced two kinds of oil palm plywood i.e., MR and WBP Grade 1 while another factory produced only one type of plywood i.e., WBP Grade 2. Allocations were used at the first factory based on the percentage of the production.

\subsection{Life Cycle Inventory}

Foreground data were collected directly from the two oil palm plywood factories in Peninsular Malaysia through questionnaires. The data gap was completed by calculation and literature reports and the data were validated by on-site visits, telephone conversations, on-site measurements, fax, literature reports and calculations.

\subsection{Life Cycle Impact Assessment}

The system boundary for LCIA started from the transportation of oil palm trunks from the plantation to the plywood factory and ends at the packaging of the oil palm plywood. Modeling of environmental impact was carried out using The SimaPro 7.1 software. The LCA methodology used was Eco-indicator 99. This methodology uses damage oriented approach or endpoint approach for impact assessment. There were eleven impact categories considered in this study and 
they are carcinogen, respiratory organic and inorganic, climate change, ionizing radiation, ozone layer depletion, ecotoxicity, acidification or eutrofication, mineral depletion and fossil fuel depletion.

\subsection{Exclusion}

Buildings and machineries, road works, workers and land use were not considered in this study.

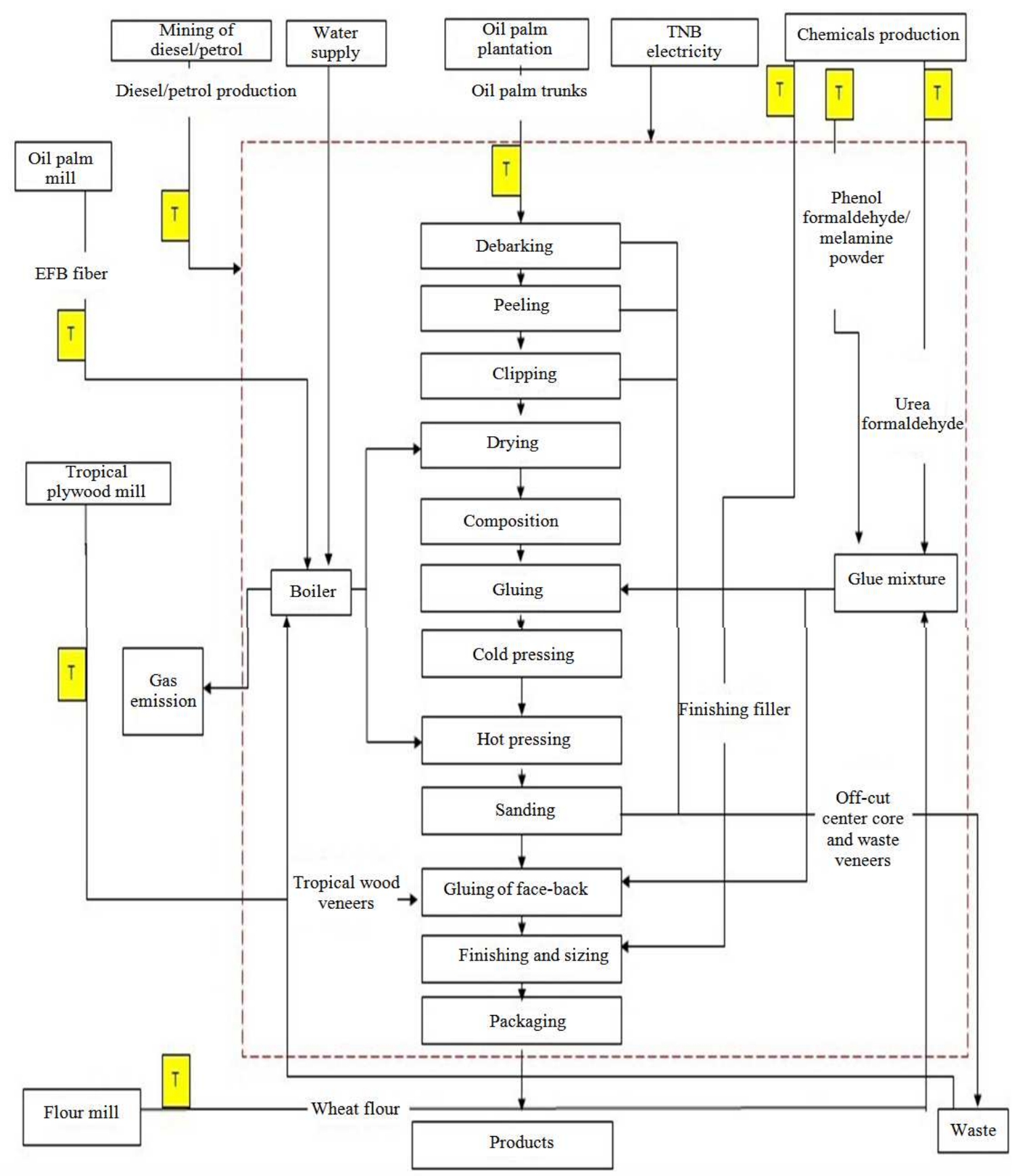

Fig. 1. General system boundary and flow chart for palm plywood production 


\section{RESULTS}

\subsection{Result Life Cycle Inventory}

LCI result is shown in Table 1. The water consumption data showed a wide range because of boiler efficiency and defect such as leaking. From this study, water consumption did not affect much on the environment, so the impact wide value can be ignored.

\subsection{Characterization Result}

Characterization results for MR palm plywood, WBP Grade 1 and WBP Grade 2 palm plywood are shown in Fig. 2-4 respectively. The characterization result for MR palm plywood indicates that the most significant life cycle is the production of urea formaldehyde, followed by lorry operation for transporting oil palm trunks from plantation to factory and generation of electricity from the grid.

\subsection{Weighting Result}

Weighting results for MR, WBP Grade 1 and WBP Grade 2 for oil palm plywood production are shown in Fig. 5-7 respectively. The most significant impacts observed from this study are the depletion of fossil fuel followed by respiration inorganic and climate change.

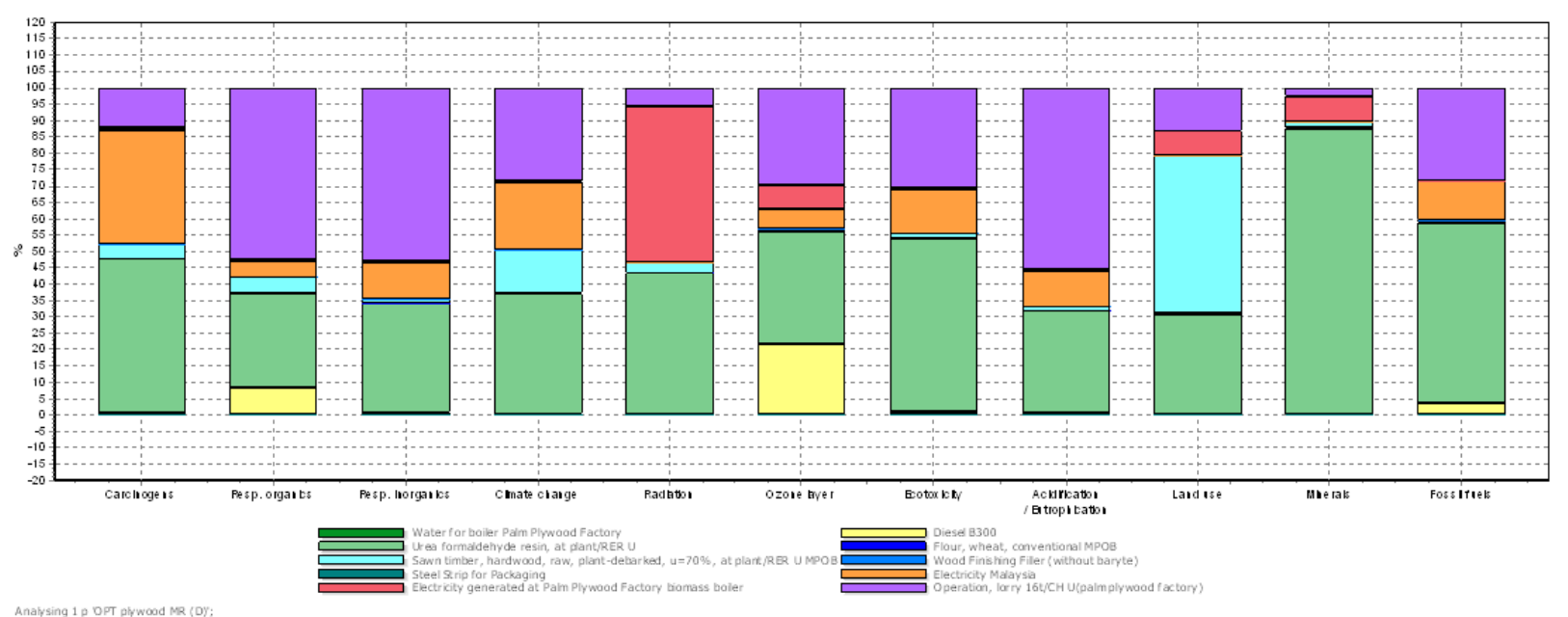

Fig. 2. Characterization for Life Cycle Impact Assessment (LCIA) of $1 \mathrm{~m}^{3} \mathrm{MR}$ palm plywood

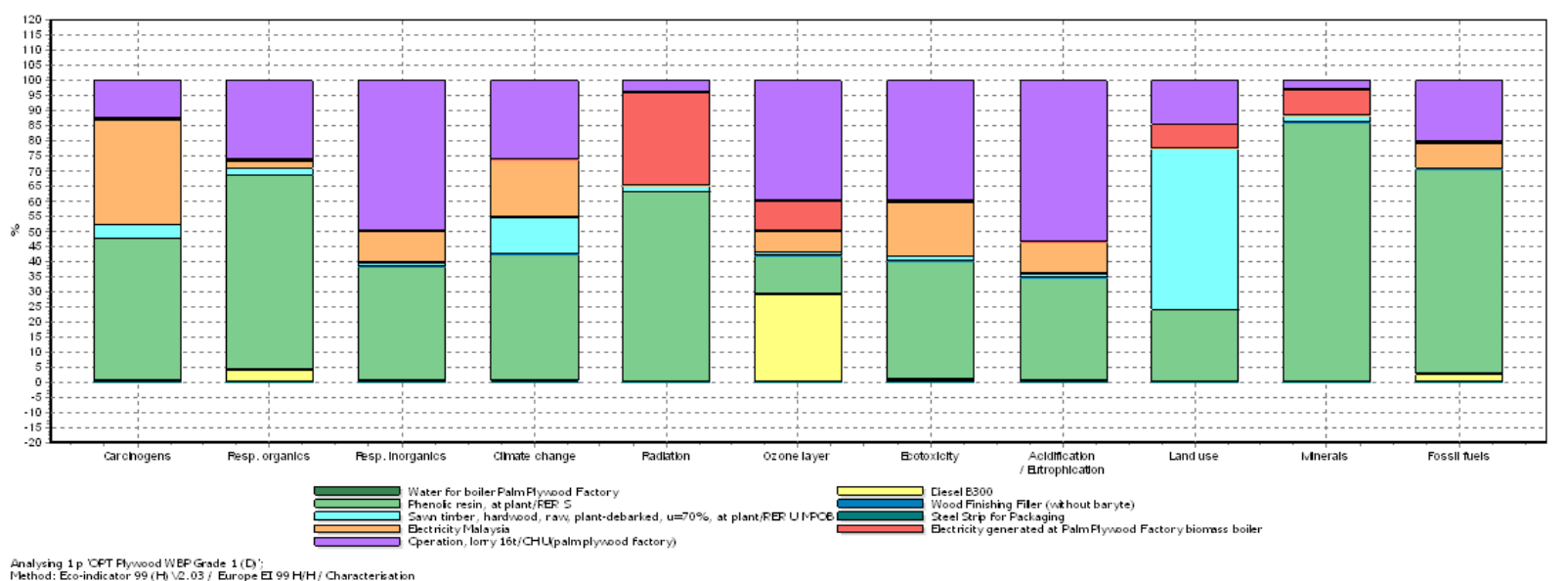

Fig. 3. Characterization for Life Cycle Impact Assessment (LCIA) of $1 \mathrm{~m}^{3}$ WBP Grade 1 palm plywood 


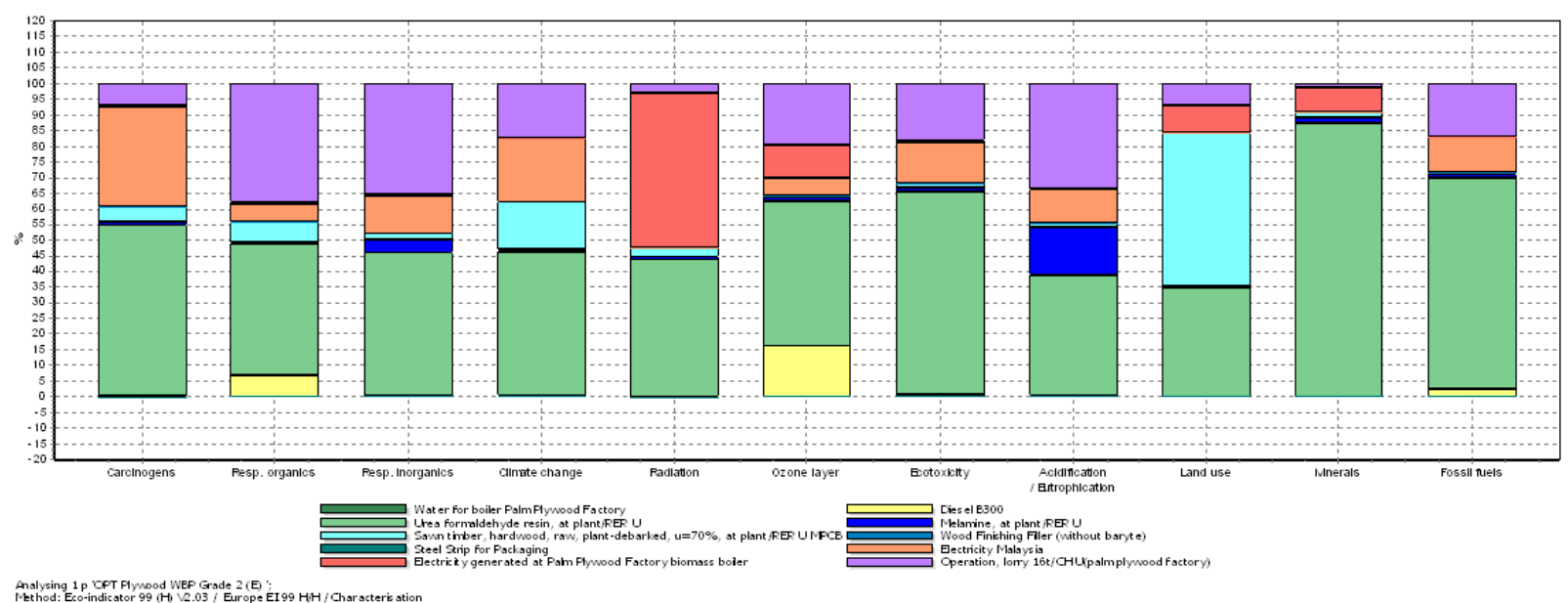

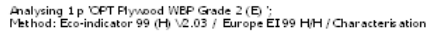

Fig. 4. Characterization for Life Cycle Impact Assessment (LCIA) of $1 \mathrm{~m}^{3}$ WBP Grade 2 palm plywood

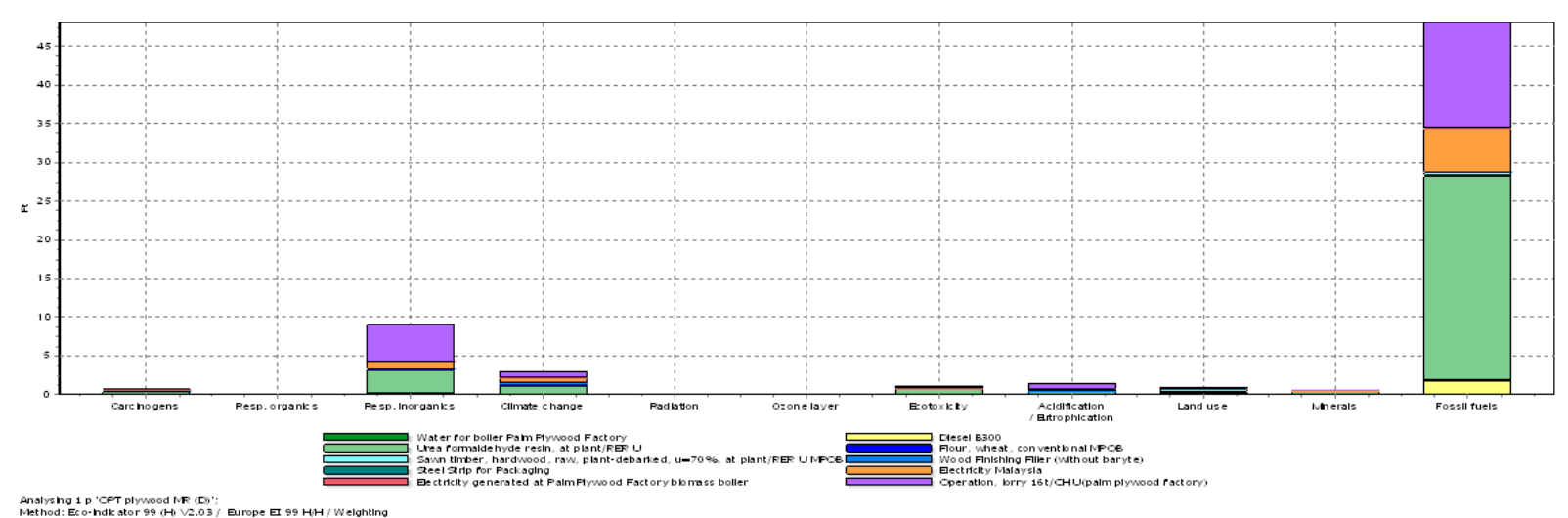

Fig. 5. Weighting for life cycle impact assessment of $1 \mathrm{~m}^{3}$ MR palm plywood

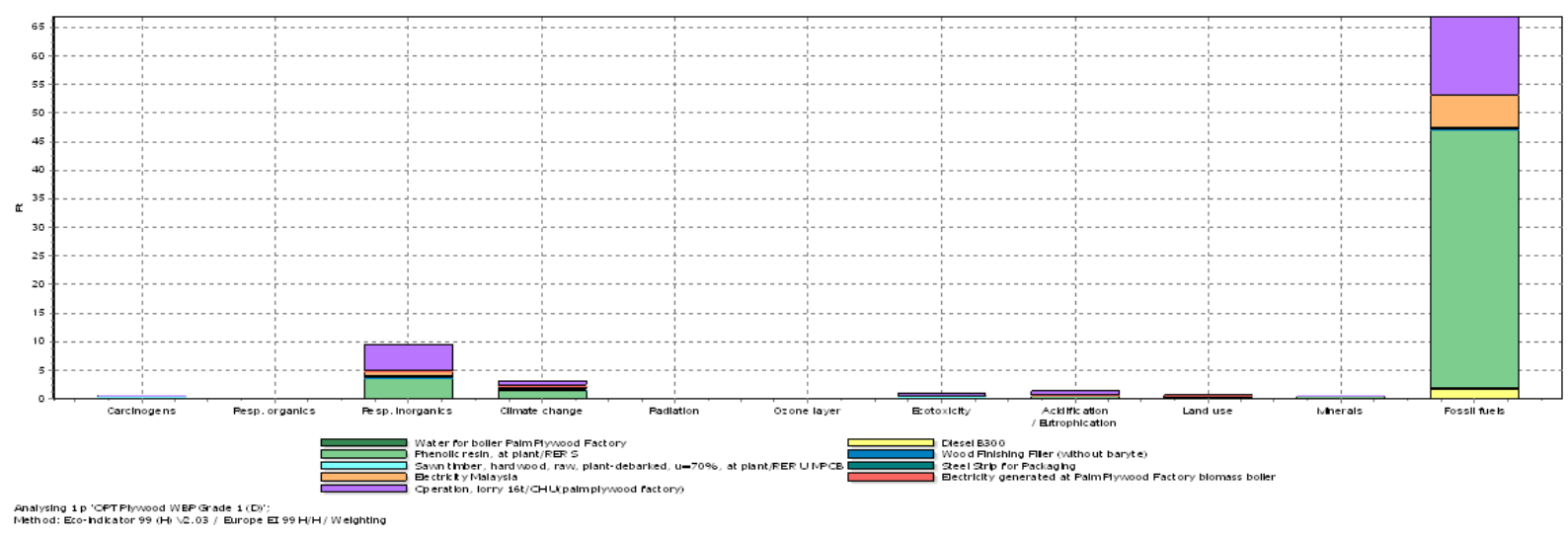

Fig. 6. Weighting for life cycle impact assessment of $1 \mathrm{~m}^{3}$ WBP Grade 1 palm plywood 


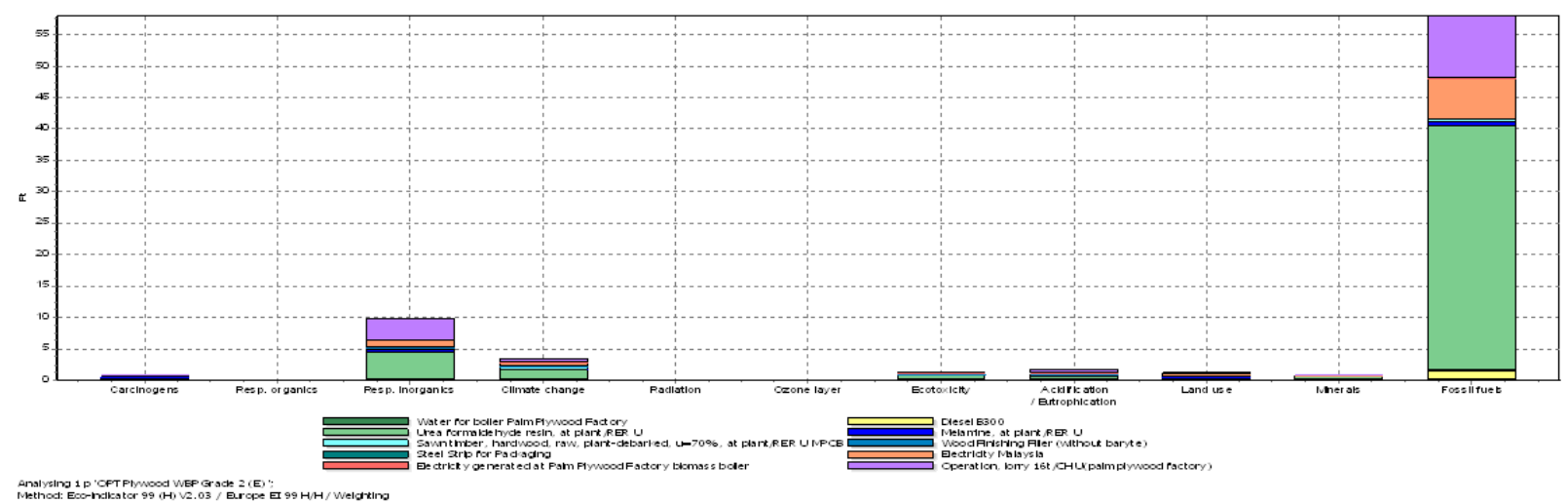

Fig. 7. Weighting for life cycle impact assessment of $1 \mathrm{~m}^{3}$ MR palm plywood

Table 1. Summarized materials and energy inputs and outputs associated with the production of palm plywood from LCI

\begin{tabular}{lccc}
\hline & $\begin{array}{l}\text { Types of palm } \\
\text { based plywood Moisture } \\
\text { Resistance (MR) }\end{array}$ & $\begin{array}{l}\text { Weather Boiling Proof } \\
\text { (WBP) Grade 1 }\end{array}$ & $\begin{array}{c}\text { Weather Boiling } \\
\text { Proof (WBP) Grade 2 }\end{array}$ \\
\hline $\begin{array}{l}\text { Parameter } \\
\text { fonsumption of oil palm trunks }\end{array}$ & 2.90 & 2.90 & 2.70 \\
Transportation operation of oil & & & \\
palm trunks from plantation to factory $(\mathrm{km})$ & 250.00 & 250.00 & 180.00 \\
Electricity from grid $\left(\mathrm{kWh} / \mathrm{m}^{3}\right)$ & 177.08 & 177.08 & 204.890 \\
Water consumption for boiler $\left(\mathrm{kg} / \mathrm{m}^{3}\right)$ & 0.90 & 0.90 & 1332.900 \\
Diesel consumption for traction $\left(\mathrm{kg} / \mathrm{m}^{3}\right)$ & 7.00 & 7.00 & 5.680 \\
Urea formaldehyde $\left(\mathrm{kg} / \mathrm{m}^{3}\right)$ & 92.50 & - & 136.585 \\
Phenol formaldehyde $\left(\mathrm{kg} / \mathrm{m}^{3}\right)$ & - & 86.33 & - \\
Melamine powder $\left(\mathrm{kg} / \mathrm{m}^{3}\right)$ & - & - & 1.46 \\
Wheat flour $\left(\mathrm{kg} / \mathrm{m}^{3}\right)$ & 18.520 & 9.000 & - \\
Finishing filler $\left(\mathrm{g} / \mathrm{m}^{3}\right)$ & 9.000 & 3.100 & 48.000 \\
Metal strips for packaging $\left(\mathrm{m} / \mathrm{m}^{3}\right)$ & 3.100 & 7.810 & 3.100 \\
Energy produced by boiler $\left(\mathrm{kWh} / \mathrm{m}^{3}\right)$ & 7.810 & 0.103 & 5.110 \\
Tropical wood veneers $\left(\mathrm{m}^{3} / \mathrm{m}^{3}\right)$ & 0.103 & 123.000 & 0.136 \\
Oil palm biomass waste $\left(\mathrm{kg} / \mathrm{m}^{3}\right)$ & 123.000 & & 378.000 \\
\hline
\end{tabular}

\section{DISCUSSION}

\subsection{Environmental Hotpots}

For the production of MR, WBP Grade 1 and WBP Grade 2 palm plywood, the weighted results using Ecoindicator 99 showed the following impacts which are the most significant (in descending order): Depletion of fossil fuel, respiration inorganic and climate change. The impact categories of fossil fuel, respiration inorganic and climate change originate from the production of adhesives (urea formaldehyde and phenol formaldehyde), lorry operation for transporting oil palm trunks and generation of electricity from the grid.

The impacts from the usage of adhesives come from the production thier stages. Formaldehyde is a toxic substances uses widely in almost types of adhesives production (WHO, 2001). The Production of urea also releases Nitrogen Oxide, a kind of greenhouse gases which is more powerful in trapping the heat compared to Carbon dioxide and the production of phenol require hydrocarbon as main material and phenol itself is a toxic substance to human (Silva et al., 2013).

The impacts from the transportation mainly come from the consumption of fuel and emission from the exhaust. The emission of carbon dioxide from fuel combustion contributes to global warming and emission of toxic substances cause harms to human health (Fuglestvedt et al., 2008).

The impacts from the usage of electricity from the grid come from the generation stage. In Malaysia, electricity is generated mainly from the combustion of natural gas $(62.6 \%)$, coal $(20.9 \%)$ (ECM, 2007). The combustion of fossil fuel releases greenhouse gases 
(such as carbon dioxide and nitrogen oxide) and toxic substances (such as heavy metal and carbon monoxide) (IPCC, 2007).

\section{CONCLUSION}

The production of oil palm plywood has significant impact on the environment from lorry operation of oil palm trunk transportation while other major impacts come from upstream industries such as the production of phenol formaldehyde or urea formaldehyde and generation of electricity at the power plant. Recommendations to improve environmental performance are by using environmental friendly adhesive such as pyrolisis oil adhesive which could be obtained from oil palm biomass to substitute the application of urea formaldehyde and phenol formaldehyde (Gallivan and Matschei, 1980; Nakos et al., 2004) and to establish several centralized collecting centres for oil palm trunks for reduction the distance of transportation, integrate the transportation of oil palm trunks based on region and using oil palm biomass in biomass boiler as an energy source efficiently to substitute energy from the grid.

This LCA study is limited to Malaysian Peninsular region and the data ware obtained between 2008-2010 time frame. It does not differentiate the energies based on their quality. All energy usage is represented by $\mathrm{kWh}$ energy currency. This study is a Gate-to-gate LCA, it does not include the cultivation of oil palm trunks and covers only the production stages. In other words, the study does not directly linked to main oil palm industry supply chain. Futhermore, land use impact category also has been ignored in this study in order to make a relevent interpretation (without cultivation at the plantation stages).

This LCA study would initiate more LCA studies to be linked together and will cover the entire oil palm supply chains. Researches for product improvement especially on environmental friendly adhesive such as pyrolisis oil from oil palm biomass will be a good initiative in order to achieve a greener oil palm based plywood industry.

\section{ACKNOWLEDGEMENT}

The researcher would like to thank UKM and MPOB for providing the facilities for the research work and the oil palm plywood factories for allowing us to conduct the study at their factories.

\section{REFERENCES}

BNM, 2011. Economic development in 2011. BNM.
Choo, Y.M., M. Halimah, H. Zulkifli, S. Vijaya and W.P. Chiew, 2011. Determination of GHG contributions by subsystems in the oil palm supply chain using the LCA approach. Int. J. Life Cycle Assess., 16: 669-681. DOI: 10.1007/s11367-011-0303-9

ECM, 2007. Summary: Primary Energy Supply. Energy Commission of Malaysia.

Fuglestvedt, J.S., T. Berntsen, G. Myhre, K. Rypdal and R.B. Skeie, 2008. Climate forcing from the Transport Sectors. Proc. Nat. Acad. Sci., 105: 454458. DOI: 10.1073/pnas.0702958104

Gallivan, R.M. and P.K. Matschei, 1980. Fractionation of oil obtained by pyrolysis of lignocellulosic materials to recover a phenolic fraction for use in making phenolformaldehyde resins. USA Pat, 4: 209-647.

Goedkoop, M. and R. Spriensma, 1999. Eco-indicator99A damage oriented method for life cycle assessment. Eco-indicator 99 methodology report.

Halimah, M., B.S. Ismail, S. Salmijah, Y.A. Tan and Y.M. Choo, 2012. A gate-to-gate case study of the life cycle assessment of an oil palm seedling. Tropical Life Sci. Res., 23: 15-23.

Halimah, M., H. Zulkifli, S. Vijaya, A.T. Yew and C.W. Puah, 2010. Life cycle assessment of oil palm seedling production (Part 1). J. Oil Palm Res., 22: 878-886.

IPCC, 2007. IPCC fourth assessment report: Climate change 2007. IPCC.

ISO, 2006. ISO 14044: Environmental management-Life cycle assessment-requirements and guidelines. ISO, Geneva, Switzerland.

Nakos, P., S. Tsiantzi and E. Athanassiadou, 2004. Wood Adhesives Made with Pyrolysis oil. A.C.M. Wood Chemicals plc.

Puah, C.W., Y.M. Choo and A.N. Ma, 2010. Life cycle assessment for the production and use of palm biodiesel (Part 5). J. Oil Palm Res., 22: 927-933.

Puah, C.W., Y.M. Choo and S.H. Ong, 2013. Production of palm oil with methane avoidance at palm oil mill: A case study of cradle-to-gate life cycle assessment. Am. J. Applied Sci., 10: 1351-1355. DOI: 10.3844/ajassp.2013.1351.1355

Silva, L.D.A., A.C. Mendes, L.D. Veranda, A.R. Ometto and R.F.A. Lahr, 2013. Life cycle assessment of urea formaldehyde resin: Comparison by CML (2001), EDIP (1997) and USEtox (2008) methods for toxicological impact categories. Proceedings of the CIRP 20th International Conference on Life Cycle Engineering, Apr. 17-19, Springer, Singapore, pp: 529-534. DOI: 10.1007/978-981-4451-48-2_86 
Tan, Y.A., M. Halimah, H. Zulkifli, S. Vijaya and C.W. Puah, 2010. Life cycle assessment of refined palm oil production and fractionation (Part 4). J. Oil Palm Res., 22: 913-926.

UMP, 2002. Projek Penyelidikan dan Pembangunan bahan binaan alternatif daripada sisa pertanianbatang kelapa sawit. University of Malaya Press, Kuala Lumpur, Malaysia.

Vijaya, S., Y.M. Choo, M. Halimah, H. Zulkifli and A.T. Yew, 2010a. Life cycle assessment of the production of crude palm oil (Part 3). J. Oil Palm Res., 22: 895903.
Vijaya, S., Y.M. Choo, M. Halimah, H. Zulkifli and A.T. Yew, 2010b. Life cycle assessment of the production of crude palm kernel oil (Part 3a). J. Oil Palm Res., 22: 904-912.

WHO, 2001. Phenol. World Health Organization.

Zulkifli, H., M. Halimah, K.W. Chan and M.W. Basri, 2010. Life cycle assessment for oil palm fresh fruit bunch production from continued land use for oil palm planted on mineral soil (Part 2). J. Oil Palm Res., 22: 887-894. 